\title{
Local values of Buginese Culture in the practice of government organizations in Sinjai
}

\section{Nilai-nilai lokal Budaya Bugis dalam praktik organisasi pemerintahan di Sinjai}

\begin{abstract}
Andi Lukman Irwan'ㄹ, Hamka Naping², Andi Ahmad Yani³ ${ }^{3}$ Muhammad Kamil Jafar $\mathrm{Nassa}^{4}$

1Department of Government, Hasanudddin University. Indonesia. E-mail: a.lukmanirwan@unhas.ac.id 2Department of Anthropology, Hasanuddin University. Indonesia. E-mail: hamka_naping@yahoo.com ${ }^{3}$ Department of Political Science, Leiden University. Netherlands. E-mail: aayani@fsw.leidenuniv.nl ${ }^{4}$ Department of Anthropology, Hasanuddin University. Indonesia. E-mail: $\underline{\text { muhkamiliafar@gmail.com }}$
\end{abstract}

\begin{tabular}{l} 
ARTICLE INFO \\
\hline Keywords: \\
Local wisdom; Bugis \\
culture; government; \\
organization. \\
How to cite: \\
Irwan, A.L., Naping, H., \\
Yani, A.A., Nassa, M.K.J. \\
(2020). Nilai-nilai lokal \\
Budaya Bugis dalam \\
praktik organisasi \\
pemerintahan di Sinjai. \\
ETNOSIA: Jurnal \\
Etnografi Indonesia. 5(1): \\
164-183. \\
DOI: \\
10.31947/etnosia.v5i1.10397
\end{tabular}

\section{Pendahuluan}

Kehidupan orang bugis tidak pernah terlepas dari ade (adat) yang berarti bahwa mereka memiliki aturan-aturan ideal yang harus dilakukan sebagai orang Bugis. Keseluruhan tingkah laku mereka penuh dengan nilai-nilai yang mengatur tatanan sosial. Berbagai adat dalam kebudayaan orang Bugis dapat kita temukan di berbagai tulisan Lontara. Keseluruhan itu berusaha menjelaskan mengenai hal-hal yang menggoda manusia 
sehingga tidak jarang mereka menyimpang dari kemanusiaan, lalu mereka menderita beban mental berupa penyesalan ketika melanggar $a d e^{\prime}$ (adat), oleh sebab itu nilai-nilai orang Bugis wajib diterapkan dalam keseluruhan kehidupan masyarakat. Menurut Toriolo, yang menentukan manusia ialah berfungsi dan berperannya sifat-sifat kemanusiaan, sehingga orang menjadi manusia, begitu juga nilai-nilai kebudayaan Bugis (Rahim : 2011).

Setiap nilai dalam kebudayaan Bugis memiliki peranan dalam berbagai kegiatankegiatan, baik dikalangan individu maupun institusi kemasyarakatan. Peranannya yang lestari dalam rangkuman masa yang cukup panjang dalam kehidupan generasi ke generasi. Peranannya yang memberikan sanksi hukuman atas setiap pelanggaran terhadapnya serta peranannya dalam memberikan penghargaan kepada yang mengembannya, baik manusia maupun lembaga dab pranata-pranata sosial.

Sejarah pemerintahan kerajaan-kerajaan orang Bugis menunjukkan berbagai $a d e^{\prime}$ (adat) dalam menunjukkan sikap perilaku dalam melayani masyarakat. Ada norma yang harus diatati secara kolektif dan jika dilanggar akan mendapatkan sanksi. Dalam konsep kerajaan orang Bugis, dikenal pula konsep panggandereng yang berfungsi mengatur pelbagai hal dalam kehidupan sosial. Konsep panggandereng ini memiliki empat unsur utama ialah ade' (adat), rapang (undang-undang), wari" (aturan perbedaan pangkat kebangsaan), bicara (ucapan, bicara), dan sara (hukum syariat Islam).

Sikap jujur, kepatutan, dan keadilan yang ditunjukkan para aparatur negara dalam budaya organisasi mereka adalah sebuah ade' (adat) sebagai orang Bugis, mereka melakukan yang pantas dilakukan dan kita lakukan; kata yang patut dikatakan dan kita katakan. Ia menghimpun orang banyak supaya tidak bercerai-berai; pagar bagi negeri supaya tidak dimasuki perbuatan sewenang-wenang; tempat mengayom orang lemah yang jujur. Berdasarkan ini, maka jelas adat mengajarkan tentang kepatutan, kejujuran, keadilan, kebenaran, sedangkan tujuannya ialah kemaslahatan manusia karena berfungsi dan berperannya nilai-nilai tersebut.

Dengan dasar dan landasan dari ade' (adat) tersebut orang-orang Bugis yang melaksanakan tugas sebagai aparatur pelayanan masyarakat (pemerintahan) bisa menjadi pelayan yang memegang prinsip good governance. Nilai yang terkandung dalam ade' (adat) tersebut harusnya bisa diterapkan dalam pelaksanaan tugas pokok dan fungsi seorang aparatur negara. Fenomena di kantor Dinas Penanaman Modal dan Pelayanan Terpadu Satu Pintu (selanjutnya disingkat DPMPTSP) Kabupaten Sinjai berkenaan dengan budaya organisasi pemerintahan mereka cukup unik, karena visi misi mereka mengambil kutipan dari nilai-nilai lokal orang Bugis dan perilaku, interaksi, serta pemberian pelayanan kepada masyarakat sangat menjunjung tinggi nilai-nilai kebudayaan Bugis. Hal ini sejalan dengan studi Painter dan Peters (2010) yang menyatakan bahwa pengaruh tradisi pemerintahan kerajaan-kerajaan kuno tidak bisa dihilangkan dalam mengelola birokrasi negara-negara modern saat ini. Secara spesifik, Yani (2016) memetakan tradisi administrasi Bugis berdasarkan Lontara Latoa dengan pengaruhnya dengan sistem pemerintah daerah di Sulawesi Selatan. 
Penelitian Munadah (2006) mengenai studi perilaku birokrasi orang Makassar di Kabupaten Gowa, menunjukkan bahwa birokrasi yang diperankan oleh orang-orang Makassar merupakan sistem sosial budaya yang bertumpu pada penghayatan, pengalaman dan pengamalan terhadap nilai-nilai siri' dalam sistim sosial panggandakkang pada interaksi pelayanan publik. Nilai-nilai siri' mendorong tumbuhnya sikap dan perilaku; jujur, cerdas dan berani yang merupakan suatu kesatuan yang utuh. Akan tetapi siri' telah mengalami pergeseran makna dan fungsi yang sudah berbeda dari akarnya dalam performa birokrasi. Studi Mariana (2007) berkenaan pengaruh budaya organisasi terhadap perilaku pejabat publik di Provinsi Jawa Barat. Hasil penelitian menunjukkan bahwa budaya organisasi yang dipengaruhi oleh nilai-nilai kolektif dan cenderung konservatif berpengaruh terhadap perilaku pejabat publik yang menyimpang. Immanuel (2006) telah meneliti pengaruh pengembangan organisasi dan budaya organisasi terhadap efektivitas keorganisasi Lembaga Perkreditan Desa di Bali, menunjukkan bahwa pengembangan organisasi, budaya organisasi berpengaruh terhadap efektivitas keorganisasian. Gunawan (2004) yang meneliti pengaruh reformasi sistim birokrasi terhadap pelaksanaan otonomi daerah di Kabupaten Kendari, dengan variable sistim birokrasi seperti struktur, perilaku birokrat, unjuk kerja dan rekruitmen menunjukkan bahwa variabel-varaibel tersebut perpengaruh terhadap pelaksanaan otonomi, walaupun secara dimensional pengaruhnya sangat kecil.

Penelitian tentang Budaya Patron-klien terhadap perilaku birokrasi di Daerah dilakukan oleh Kausar A.S (2006) menujukkan bahwa budaya patron-klien sangat mempengaruhi kinerja birokrasi pemerintah daerah, utamanya memperlemah kinerja birokrasi dengan perilaku birokrasi yang menyimpang. Parhusip (2006) telah melakukan penelitian tentang pengaruh desain pekerjaan dan kompetensi terhadap kepuasan kerja dan implikasinya kepada kinerja pegawai. Hasilnya secara deskriptif kepuasan desain pekerjaan dan kepuasan kerja rendah, namun secara koretaif memiliki hubungan. Dalam studi Hardianti Munsi, dkk (2018) menemukan hasil penelitian bahwa bagi orang Bugis, bisnis tidak dapat dipisahkan dengan tujuan untuk mendapatkan pengakuan sosial. Terlebih lagi jika bisnis yang dijalankan merupakan usaha yang melibatkan nama baik keluarga. Demi menjaga itu semua, perusahaan terus mengupayakan peningkatan peforma finansial yang dimiliki dan terus berperan aktif untuk mengawasi.

Berdasarkan hasil beberapa penelitian seperti Gunawan (2004), Munadah (2006), Immanuel (2006) dan Mariana (2007) berkenaan pelayanan dan pelaksanaan birokrasi mereka melakukan kajian berfokus kepada faktor yang menghambat peningkatan pelayanan di beberapa daerah, sedangkan penelitian dari Kausar AS (2006), Parhusip (2006), dan Hardianti (2018) menunjukkan pola pembentukan suatu sistem budaya organisasi yang dipengaruhi dari berbagai faktor. Artikel ini memiliki perbedaan perspektif dari penelitian sebelumnya, menjadikan nilai lokal sebagai objek dan fokus yang menjadi faktor utama dalam mendorong untuk menciptakan good governance pada sebuah budaya organisasi pemerintahan dengan metode kualitatif. fokus artikel ini akan membahas perihal nilai-nilai lokal yang terimplikasikan dalam sebuah budaya organisasi pada sebuah sistem pemerintahan di Kabupaten Sinjai. Artikel ini bertujuan 
untuk memberikan dua pokok penjelasan, yaitu (1) bahwa dalam sebuah sistem birokrasi pemerintahan terdapat sebuah budaya organisasi yang unik, tidak hanya mengadopsi sistem pemerintahan modern namun juga tetap masih mempertahan nilai ade' (adat) yang menjadi landasan utama perilaku orang Bugis, dan (2) mengungkapkan implikasi dari penerapan nilai-nilai lokal tersebut kepada sistem pelayanan publik di Kabupaten Sinjai.

\section{Metode}

Penelitian ini menggunakan metode kualitatif, khususnya studi tentang budaya lokal dan budaya organisasi birokrasi. Sebagaimana penelitian mengenai budaya, maka budaya lokal pada organisasi birokrasi sebagai unit analisis untuk diteliti. Dengan demikian, unit analisis dalam penelitian ini adalah organisasi karena perilaku birokrasi merupakan interaksi antara budaya lokal dengan budaya organisasi. Jenis data dan teknik pengumpulan data terbagai atas dua yaitu primer dan sekunder. Data primer terdiri atas; (1) hasil observasi dan wawancara dari keseluruhan informan berkenaan dengan topik nilai-nilai lokal dan budaya organisasi, (2) Profil dari kantor DPMPTSP berkenaan Visi-Misi Kantor yang mencantumkan nilai-nilai lokal, (3) Standar operasional prosedur dan tugas pokok dan fungsi para aparatur. Data sekunder terdiri atas; dokumen-dokumen yang peneliti temukan baik di kantor DPMPTSP dan media online (website resmi kantor dan kabupaten).

Kemudian teknik pengumpulan data pada studi ini, pertama-tama dilakukan pencarian dokumen dan rekaman arsip, dokumen dan arsip yang dipilih tentunya relevan dengan tujuan penelitian, selanjutnya melakukan observasi terhadap aktivitas dan perilaku aparatur birokrasi dalam melaksanakan tugas pelayanan umum. Peneliti melakukan wawancara mendalam dengan menggunakan pedoman wawancara. Pedoman wawancara ini berisi pertanyaan-pertanyaan pokok dari masing-masing fokus dan akan dikembangkan selama wawancara berlangsung. Wawancara akan berfokus pada pengalaman, pendapat, perasaan, pengetahuan, indera, dan latar belakang informan yang berkaitan dengan fokus yang sedang diteliti. Informan kunci dalam penelitian ini ialah Kepala Dinas DPMPTSP Kabupaten Sinjai. Dalam proses wawancara peneliti juga bertemu bersama beberapa kepala bagian, kepala sesi, dan pegawai serta beberapa masyarakat untuk melakukan wawancara mendalam, proses ini memakan waktu yang cukup lama karena peneliti melakukan wawancara dibeberapa tempat agar informan dapat terbuka dan tidak merasa sedang dalam ruang lingkup pekerjaan. Setelah data primer dan sekunder terkumpul dilakukan teknik analisis data kasus dengan melalui tiga tahap yaitu reduksi data, penyajian data dan pengambilan kesimpulan.

\section{Hasil dan pembahasan}

\section{- Nilai-nilai lokal dalam praktik organisasi}

Budaya organisasi merupakan nilai dan keyakinan bersama yang mendasari identitas organisasi yang mengacu ke suatu sistem makna bersama yang dianut oleh anggotaanggota yang membedakan organisasi itu dengan organisasi-organisasi lain. E.H. Schain (1992) mendefinisikan budaya organisasi sebagai Suatu pola yang disepakati sebagai 
asumsi dasar bagi kelompok untuk belajar menyelesaikan masalah-masalah adaptasi eksternal dan integrasi internal, hal tersebut telah cukup bekerja baik untuk dianggap valid dan benar untuk mengenali, berpikir dan merasakan hubungan masalah-masalah tersebut.

Secara keseluruhan peneliti menemukan enam (6) nilai-nilai lokal yang telah masuk dalam budaya organisasi di kantor DPMPTSP kabupaten Sinjai yaitu; (1) lempu (jujur), (2) amaccang (kecendikiaan), (3) astinajang (kepatutan), (4) aggatenggeng (keteguhan), (5) sipakatau dan sipakainge, dan (6) ajjoareng. Keenam nilai ini menjadi landasan para aktor dalam menunjukkan sikap baik kepada sesama aparatur dan kepada masyarakat yang menerima pelayanan mereka. Dengan demikian, nilai-nilai tersebut merupakan bagian dari budaya lokal. Budaya lokal yang dimaksud ialah pada bagaimana interaksi terjadi antara warga atau masyarakat pengguna layanan DPMPTSP dengan birokrasi dan mekanisme pelayanan yang terdapat didalam DPMPTSP. Lebih lanjut, budaya lokal yang dimaksud lebih merujuk pada hubungan sosial-budaya yang "hidup" dikalangan masyarakat Sinjai yang mana bentuk hubungan sosial-budaya ini terdapat dalam pertemuan antara budaya lokal dan birokrasi, dan antara budaya lokal dengan pelayanan publik.

Berdasarkan sejarah kerajaan orang-orang Bugis, telah memiliki sistem kerajaan yang mereka sebut dengan istilah panggandereng dalam melayani kebutuhan masyarakat. Unsur dari panggandereng ialah; Unsur-unsur panngadereng, yaitu ade' (adat), rapang (undang-undang), wari" (aturan perbedaan pangkat kebangsaan), bicara (ucapan, bicara), dan sara (hukum syariat Islam). Dari data tersebut kita dapat menemukan bahwa sistem pemerintahan saat ini tidak hanya mengadopsi sistem pemerintahan modern namun masih memilki ciri khas budaya Bugis dalam interaksi aparatur dan sistem pelayanan yang mereka lakukan. Berikut beberapa nilai lokal Bugis yang masih dipraktekkan dalam budaya organisasi pemerintahan di Kabupaten Sinjai;

\section{Nilai budaya lempu' (Jujur)}

Dalam perkataan orang Bugis, jujur disebut lempu'. Lempu' berarti “lurus" yang merupakan antonim dari kata 'bengkok'. Penggunaan kata tersebut dalam berbagai konteksnya, berarti juga ikhlas, benar, baik atau adil. Misalnya, laleng malempu' artinya jalan yang lurus. Dengan demikian antonim kata-kata tersebut yaitu curang, culas, dusta, khianat, seleweng, buruk, tipu, aniaya, dan semacamnya.

Orang Bugis mempunyai nilai budaya siri' (malu) dan pesse (solidaritas). Prinsip ini, bagi masyarakat Bugis adalah sebagai suatu norma yang sangat dihormati, karena hal itu merupakan bukti bahwa seseorang dapat menjaga kesucian diri dan kehormatannya. Dalam kaitan ini, syair orang Bugis menyebutkan:

"Duwai kuala sappo; unganna panasae, belona kanukue" Artinya "Dua (hal) yang kujadikan pagar (pelindung diri dan kehormatan), yaitu bunga nangka dan hiasan kuku". Kata 'panasa' pada 'unganna panasae' yang sinonim dengan kata "lempu". Bila diberi tekanan glottal stop (') pada suku kata terakhir menjadi lempu', maka kata itu berubah maknanya menjadi 'kejujuran'. Demikian pula kata "belona kanukue", digunakan untuk hiasan kuku (belo kanuku) yang disebut pacci. Kata pacci, bila 
mendapat tambahan bunyi " $n g$ " pada akhir kata pacci menjadi paccing, maka kata itu berubah arti menjadi tidak ternoda, bersih, atau suci. Dengan demikian, "Duwai kuala sappo; unganna panasae, belona kanukue" dapat diartikan "dua yang senantiasa dijadikan pagar yaitu kesucian dan kejujuran".

Kesucian yang dimaksud dalam hal ini adalah suci dalam hati dan tindakan. Suci dalam hati itu mengandung arti adanya ketulusan hati, kebeningan jiwa, pemikiran positif, tidak iri, dan sebagainya. Sedangkan suci dalam tindakan adalah menjaga hal-hal yang memalukan, baik dalam perspektif budaya maupun perspektif agama. Dalam konteks penyelenggaraan pelayanan dan birokrasi "paccing" bermakna tidak melakukan hal-hal yang memalukan seperti meminta pungutan liar dan menyulitkan proses birokrasi namun selalu ikhlas dan jujur dalam menjalankan tugas pokok dan fungsi sebagai aparatur negara, kondisi ini sangat mencerminkan proses pelayanan di Kantor DPMPTSP di Kabupaten Sinjai dalam praktek yang mereka lakukan sangat menjunjung tinggi sikap ikhlas dan jujur, mereka senantiasa melayani sesuai dengan standar operasional (SOP) dengan menjunjung tinggi nilai lempu' tersebut.

Kejujuran (lempu') merupakan nilai utama budaya masyarakat Bugis, sehingga selama nilai ini terjaga dengan baik, maka hati dan tindakannya seluruhnya menjadi lurus dan tidak terjadi hal-hal yang memalukan bagi prinsip orang bugis. Ketika Tociung, Cendikiawan Luwu, diminta nasihatnya oleh calon raja (datu) Soppeng, La Manussa' Toakkareng, Tociung menyatakan ada empat perbuatan jujur, yaitu: (1). memaafkan orang yang berbuat salah kepadanya, (2). dipercaya lalu tidak curang, artinya disandari lalu tidak berdusta, (3) tidak menyerakahi yang bukan haknya, dan (4) tidak memandang kebaikan kalau hanya untuk dirinya, baginya baru dikatakan kebaikan kalau bisa dinikmati bersama.

Dalam bahasa Bugis dikatakan:

“Eppa' gau'na lempu'e: risalaie naddampeng, riparennuangie temmacekko bettuanna risanresi teppabbelleang, temmangoangenngi tenia alona, tennaseng deceng rekko nassamarini pudeceng".

Artinya:

Ada empat inti perbuatan jujur: Memaafkan kesalahan orang lain padanya, jujur dalam menerima amanah, artinya tidak berkhianat, tidak serakah dan tidak mengambil yang bukan haknya, ia tidak menganggap kebaikan kecuali baik juga bagi orang lain.

Kondisi ini dipraktekkan dalam budaya organisasi yang ditanamkan oleh pimpinan dan bawahan yang berada di kantor DPMPTSP Kabupaten Sinjai, seluruh pimpinan dari kepala hingga kepala seksi (KASI) harus memiliki sikap amanah dalam menjalankan seluruh pekerjaan yang berhubungan dengan pelayanan dan birokrasi, mereka telah memiliki nilai lempu' dalam hati mereka sehingga dalam hubungan yang terjadi diantara mereka ketika ada yang melakukan kesalahan, mereka akan saling menegur sehingga nilai-nilai itu tetap berjalan dengan baik diantara mereka. Sejalan dengan pengertian di atas Kajaolaliddong, cendikiawan Bone, menjelaskan kejujuran ketika ditanya oleh Raja Bone mengenai pokok-pokok 
keilmuan. Apa saksinya atau bukti kejujuran? "Seruan ya Ampone!" Apa yang diserukan ya Kajao? “Adapun yang diserukan ialah:

"Aja' muala taneng-taneng tania taneng-tanengmu. aja' muala warang- parang tania warang-parangmu nataniato mana'mu, aja'to mupassu tedong natania tedongmu, enrengnge annyarang tania anynyarangmu, aja'to muala aju ripasanre' natengnia iko pasanre'i, aja'to muala aju riwetta wali netengnia iko mpetta waliwi."

Artinya:

"Jangan mengambil tanaman yang bukan tanamanmu, jangan mengambil barangbarang yang bukan barang-barangmu, bukan juga pusakamu; jangan mengeluarkan kerbau (dari kandangnya) yang bukan kerbaumu, juga kuda yang bukan kudamu, jangan ambil kayu yang disandarkan, bukan engkau yang menyandarkan, jangan juga kayu yang sudah ditetak ujung pangkalnya, yang bukan engkau yang menetaknya."

Pesan ini menunjukkan komitmen kejujuran, yakni tidak mengambil hak orang lain. Pemerintah tidak mengambil hak rakyat melalui pungutan liar dalam proses perizinan serta penyalahgunaan wewenang dan jabatan. Di dalam petuah Bugis di atas dikatakan, kayu yang sudah dipotong pertanda ada yang punya. Kalau yang tersimpan di pinggir jalan saja dipesankan agar tidak diambil, apalagi yang jelas dijaga di dalam pagar berarti jelas tidak boleh diambil karena milik orang lain.

Pesan ini diungkapkan dalam bahasa Bugis dengan sangat halus dan mengandung kedalaman makna, yakni komitmen kejujuran. Bagi orang Bugis, kandungan filosofis pesan tersebut merupakan nilai dan harga dirinya. Kejujuran (lempu') adalah harga dirinya, sehingga jika ia kehilangan kejujuran berarti kehilangan kepercayaan dan pada saat yang sama harga dirinya ikut lenyap. Sebaliknya, jika kejujuran terpelihara dengan baik, maka nilai dan harga diri serta martabat insaniyahnya ikut terpelihara dengan baik. Dalam pandangan nilai-nilai utama kebudayaaan Bugis, kesesuaian antara kata dan perbuatan disebut "taro ada taro gau" (antara kata dan perbuatan sama). "Ada" (kata) adalah pegangan, ketika ia diucapkan atau keluar dari mulut maka bukan lagi milik yang mengucapkan, sehingga ia akan menjadi alat ukur orang lain tentang orang yang mengucapkan. Pembuktiannya dalam bentuk prilaku atau perbuatan nyata. Jadi, mengeluarkan kata harus penuh pertimbangan agar tidak asal keluar tanpa makna kebaikan.

\section{Nilai budaya Amaccang (Kecendikiaan)}

Kejujuran dan kecendikiaan adalah prinsip bagi orang Bugis yang saling berhubungan. Yang dinamakan kecendikiaan adalah tidak ada yang sulit dilaksanakan, tidak ada pembicaraan yang sulit disambut, dengan kata-kata yang baik dan lemah-lembut lagi percaya kepada sesama manusia. Yang dinamakan jujur ialah perbuatan baik, pikiran benar, tingkah laku sopan lagi takut kepada Tuhan.

Dalam bahasa Bugis 'cendikia' sering diartikan ' $a c c a$ ', yaitu pandai atau pintar. Acca ini lebih kepada makna yang positif, dan tidak sebaliknya. To acca adalah orang mempunyai kearifan. Acca adalah prilaku baik cara berpikir maupun cara bertindak dapat menjadi pertimbangan yang arif. Jadi, acca bukan latar belakang pendidikan 
formal, melainkan juga nilai-nilai kearifan yang menghiasi cara berpikirnya dan bertindaknya. Tidak disebut pula To Acca kalau tidak jujur. Kalau ada orang berilmu tetapi tidak jujur, tidak pemaaf, serakah, mengambil yang bukan haknya maka hakikatnya ia tidak pandai (bukan To Acca).

Orang mempunyai nilai acca atau nawanawa oleh lontara disebut Toacca, Tokenawanawa atau Pannawanawa, yang dapat diterjemahkan menjadi cendekiawan, intelektual, ahli pikir atau ahli hikmah arif. Pengertian ini masih perlu dijelaskan guna membantu kita memahami nilai kecendekiaan yang dikemukakan oleh lontara. Dalam konsep nilai kecendekiaan terkandung, disamping nilai kejujuran, juga nilai kebenaran, kepatutan, keikhlasan, dan semangat penyiasatan atau penelitian. Tociung menyebutkan bahwa cendekiawan (toakenawanawa) mencintai perbuatan dan kata yang benar, waktu menghadapi kesulitan dia memikirkannya kembali, dan berhati-hati melaksanakan segala sesuatu. Petta Matinroe ri Lariangbanngi (bangsawan tinggi Bone) menerangkan pula bahwa yang disebut pannawanawa (cendekiawan) ialah orang yang ikhlas, yang pikirannya selalu mencari-cari sampai dia menemukan pemecahan persoalan yang dihadapinya demikian juga perbuatan yang menjadi sumber bencana dan sumber kebajikan.

Praktek nilai amaccang ini dalam proses pemberian pelayanan dan birokrasi kepada masyarakat terjadi dalam beberapa proses yang dilakukan oleh tingkatan kepala kasi hingga ke paling tinggi. Bentuknya terlaksana dalam proses pemberian izin terutama dalam perizinan perikanan dan izin membangun, sikap yang dimiliki oleh para aparatur selain harus menjalankan tugas pokok dan fungsi berdasarkan standar operasional namun mereka harus memiliki sikap amaccang dalam menghadapi masyarakat yang akan melakukan proses perizinan terutama dalam hal menjelaskan persyaratan dan kelengkapan berkas yang harus disiapkan, para aparatur dituntut untuk mempraktekkan sikap amaccang ini dalam hal menjelaskan agar masyarakat dapat terlayani dengan baik dengan prinsip kebenaran, kejujuran, dan keikhlasan.

Nilai amaccang ini juga dipraktekkan oleh seluruh pimpinan dari atas hingga bawah dalam menjalankan tugas sebagai seorang pelayan publik dalam Dinas Penanaman Modal dan Perizinan Terpadu Kabupaten Sinjai. Pembentuk pola sikap, nilai amaccang yang telah menjadi asumsi dasar bersama sumber daya manusia DPMPTSP, juga berfungsi sebagai pembentuk pola sikap agresif (tidak santai) dan kompetitif sumber daya manusia DPMPTSP dalam melaksakan tugasnya. Salah satu strategi pimpinan DPMPTSP dalam menjaga pola sikap agresif para tenaga perizinan dan non perizinan dalam bekerja, adalah: (1) mengetahui kesesuaian kompetensi yang dimiliki oleh seseorang dengan tugas yang diberikan padanya (the right man on the right place), (2) mengetahui kesesuaian waktu dengan hasil pekerjaan. (3) melaksanakan pengawasan dan apabila ditemukan kesalahan atau kekeliruan, segera dilakukan perbaikan sehingga tujuan organisasi dapat tercapai dengan efektif dan efisien, (4) menjamin agar semua pekerjaan yang sedang dilakukan bejalan sesuai dengan rencana yang telah ditentukan sebelumnya, (5) mengukur hasil kinerja, (6) mempelajari perkembangan pekerjaan secara 
berkesinambungan dengan memonitor pekerjaan yang sedang berlangsung, (7) melakukan usaha-usaha untuk mengurangi, menghindari atau malah menyelesaikan faktor-faktor yang menghambat pekerjaan, (8) menyediakan penghargaan bagi tenaga perizinan dan non perizinan yang berprestasi. Salah satu wujud dari pola sikap sumberdaya manusia DPMTPSP yang telah terbentuk adalah bekerja dengan mengutamakan proses (process oriented) untuk mendapatkan hasil (outcome oriented). Dalam memberikan pelayanan, semua aktifitas kerja mereka harus mengacu pada standar operasional prosedur (SOP).

\section{Nilai budaya Astinajang (Kepatutan)}

Asitinajang merupakan konsep nilai bugis yang mengarahkan pada kepatutan, kepantasan, kelayakan, kata ini berasal dari tinaja yang berarti cocok, sesuai, pantas atau patut. Lontara mengatakan:"Duduki kedudukanmu, tempati tempatmu. Ade' wari' (adat pembedaan) pada hakikatnya mengatur agar segala sesuatu berada pada tempatnya. Mengambil sesuatu dari tempatnya dan meletakkan sesuatu pada tempatnya, termasuk perbuatan mappasitinaja.

Dalam konteks ini juga dikatakan bahwa merusak tata tertib ini adalah kezaliman. Kewajiban yang dibaktikan memperoleh hak yang sepadan adalah suatu perlakuan yang patut. Banyak atau sedikit tidak dipersoalkan oleh sitinaja. Ambil yang sedikit jika yang sedikit itu mendatangkan kebaikan, dan tolak yang banyak apabila yang banyak itu mendatangkan kebinasaan.

Nilai kepatutan ini erat hubungannya dengan nilai kemampuan (makamaka) jasmaniah dan ruhaniah. Penyerahan atau penerimaan sesuatu, apakah itu amanat atau tugas, haruslah didasarkan atas kepatutan dan kemampuan. Makamaka lebih banyak menekankan penampilan bagi pemangku tanggung jawab. Praktek nilai kepatutan ini banyak terjadi pada pegawai yang melakukan pelayanan kepada masyarakat, mereka terus berusaha bekerja sesuai dengan tugas pokok dan fungsi, namun tidak dapat dipungkiri bahwa dalam menjalankan tugasnya selalu ada pihak-pihak yang menawarkan pemberian jika proses pengurusan perizinan mereka dapat dibantu dan dipercepat.

Namun tidak semua pemberian itu diterima oleh pegawai karena mereka memiliki prinsip nilai kepatutan terhadap aturan yang mereka miliki dalam proses pelayanan perizinan. Mereka mengatakan kalau mereka menerima sesuatu dari seseorang untuk dibantu dalam proses perizinan adalah pelanggaran dari nilai kepatutan tersebut karena dalam nilai astinajeng memberikan penjelasan bahwa orang yang memberi karena pantas memberi, dan orang yang menerima karena patut menerima. Tanggung jawab telah dilaksanakan dan amanat telah ditunaikan. Inilah alasannya jika para pegawai tersebut menolak sesuatu yang diberikan kepadanya. Kalau sampai dia terimakan sesuatu yang melanggar kepatutan tentulah dia, disamping menolak ketaklayakan itu juga mereka merasakan tak diperlakukan secara patut. Dirinya atau hasil jerih payahnya, maka dia merasakan atau kurang dari kepatutan, maka dia merasakan pemberian itu tidak pantas. Dalam beberapa kasus para pegawai emosi hingga marah dan melakukan 
penjelasan kepada para orang-orang yang akan memberikan sesuatu untuk proses perizinan, maka emosi itu mendukung dari nilai kepatuhan tersebut. Jika dia menerima keadaan yang tak patut itu maka dia melanggar nilai kepatuhan, samasama pelanggaran yang dilakukan oleh orang yang memberikan penghargaan secara tak patut itu.

Nilai astinajang ini pula dipraktek kan dalam konteks perilaku seseorang kepada orang-orang yang memiliki status berbeda, dalam konsep orang-orang bugis mereka yang menempati strata paling atas disebut bangsawan yaitu mereka yang memiliki keturunan darah biru (kerajaan). Tidak dapat dipungkiri perilaku para aparatur akan sangat berbeda ketika bertemu dengan orang biasa dan para keturunan bangsawan ada nilai yang mereka pahami bahwa mereka adalah keturunan raja yang harus diperlakukan secara berbeda. Walaupun dalam DPMPTSP Kabupaten Sinjai ini telah memiliki standar operasional prosedur yang telah mengatur bagaimana proses pemberian pelayanan serta perizinan namun beberapa kasus memperlihatkan bahwa ada perilaku yang melebihi dari standar operasional prosedur yaitu perilaku yang menghormati para keturunan bangsawab tersebut ketika melakukan mekanisme pemberian izin dan pelayanan.

Struktur sosial orang Bugis telah memberikan gambaran bahwa mereka yang dihargai dan dianggap memiliki status yang tinggi adalah mereka yang memiliki gelar bangsawan, seperangkat dengan jabatan dalam pemerintahan, dan mempunyai tingkat sosial ekonomi yang tinggi. Setiap individu berusaha mengekspresikan dirinya seperti apa yang dituntut oleh norma budaya setempat yang berlaku. Salah satu upaya untuk memenuhi nilai-nilai tersebut adalah dengan menjadi pegawai negeri. Lingkungan birokrasi dianggap merupakan tempat seperangkat simbol-simbol budaya politik, seperti kekuasaan, kontrol, penguasaan sumber daya, sampai dengan prestise keluarga maupun pribadi dengan mudah dapat diekspresikan. Perangkat nilai-nilai dan simbol dalam budaya birokrasi di DPMPTSP Kabupaten Sinjai juga banyak berbasis pada sistem nilai dan budaya yang berkembang pada masyarakat setempat. Bagi masyarakat Bugis, pola sikap dan perilaku pada dasarnya merefleksikan unsur budaya yang dikenal oleh masyarakat dengan nama astinajang (kepatuhan).

Nilai budaya tersebut menghasilkan kepatuhan dan rasa hormat masyarakat sekaligus pelayanan terhadap raja atau penguasa. Rupanya pola tersebut menjadi praktik birokrat pemerintahan pada masa sekarang ini. Respek terhadap para aristokrat yang terpelihara diantara birokrat dan secara tradisional diakui oleh masyarakat itu membawa implikasi tidak efektifnya pelayanan publik. Sistem nilai dan norma budaya Bugis yang dipakai dalam sistem birokrasi akhirnya terkesan berstandar ganda. Pada satu sisi adanya keinginan birokrasi untuk berperilaku layaknya sebagai seorang 'bangsawan' yang berkuasa yang harus dilayani, pada sisi lain birokrasi juga berfungsi sebagai pelayan yang harus mengetahui kebutuhan masyarakat yang dilayaninya. Terjadinya dualisme orientasi nilai yang berkembang di dalam sistem birokrasi telah memberikan dampak berupa munculnya sikap yang ambivalensi. Pelayanan publik bersifat ambivalen karena 
tidak ada pemisahan antara kepentingan formal kedinasan dengan kepentingan pribadi. Realitas dalam fungsi-fungsi pelayanan publik ini akan melahirkan gaya hidup feodal dalam birokrasi yang mempengaruhi perlakuan pelayanan terhadap rakyatnya.

Prinsip ini sesuai dengan warisan leluhur bugis dalam lontara: “jangan serakahi kedudukan, jangan pula terlalu menginginkan kedudukan tinggi, kalau kamu tidak mampu memperbaiki negeri. Nantilah bila dicari baru kamu muncul, nantilah baru kamu ditunjuk bari mengia". Ada empat hal yang dapat merusak nilai kepatutan tersebut ; (1) tamak atau keserakahan akan menghilangkan malu, (2) kekerasan, akan melenyapkan kasih sayang dalam negeri, (3) kecurangan, akan memutuskan hubungan orang sekluarga, (4) ketegahan akan menjauhkan kebenaran didalam kampung. Kalau keserakahan dijadikan modal akan terlepas semua yang ada di tangan. Kalau kecurangan yang dijadikan modal sulit ganjarannya, adapun jika kejujuran yang dijadikan modal, kehidupan balasannya. Sesungguhnya jikalau kepatutan yang dijadikan modal, kecemerlangan imbalannya, disudahi kebajikan dan ditutup keselamatan.

\section{Nilai budaya Agettengeng (Keteguhan)}

Dalam bahasa Bugis keteguhan adalah agettengeng. Prinsip keteguhan orang Bugis tetap pada asas atau setia pada keyakinan, atau kuat dan tangguh dalam pendirian, erat memegang sesuatu. Seperti halnya nilai kejujuran, nilai kecendikiaan, dan nilai kepatutan, maka nilai keteguhan (agettengeng) ini terikat oleh nilai positif.

Dikatakan: "Eppa gau'na gettengnge: tessalaie janci, tessorosie ulu ada, telluka anu pura teppinra assituruseng, mabbicara naparapi, mabbinru'i tepupi napaja". Artinya, (Empat nilai keteguhan; pertama, tidak mengingkari janji, kedua, tidak menghianati kesepakatan, tidak membatalkan keputusan, ketiga, tidak mengubah keputusan, dan keempat, berbicara dan berbuat, tidak berhenti sebelum rampung).

Ada pengertian lain tentang keteguhan ini. Ada dua macam nya yaitu : yang satu tidak baik dan yang lainnya adalah keteguhan yang baik. Orang yang memegang keteguhan yang baik ialah yang menetapi untuk tidak mengerjakan ketibaikkan, dan berketetapan melakukan kebaikan, meskipun keburukan itu menarik hatinya tetapi sudah diketahuinya tentang keburukan nya lalu tak dilakukannya lagi. Biarpun tadinya tidak akan dikerjakan, kemudian diketahui bahwa ia itu adalah baik, maka lantas dikerjakan.

Kepala Dinas dalam melakukan sosialisasi mengenai prinsip, tujuan dan motivasi kerja dalam pelayanan publik dan birokrasi, maka ramailah kepala bidang, kepala seksi dan diikuti oleh masing-masing anggotanya melaksankan prinsip dan tujuan dengan motivasi kerja yang telah disampaikan oleh kepala dinas. Yang menyampaikan motivasi kerja ini ialah kepala seksi di bawah kepala bidang masing-masing, sehingga proses penyampaian dapat terlaksana keseluruh stakeholder. 
Dari hasil analisis yang dilakukan maka boleh dikatakan apa yang dilakukan oleh kepala bidang dan kepala seksi bersama para anggotanya merupakan nilai keteguhan dimana mereka memegang janji atas perjanjian yang telah disepakati dalam motivasi kerja. Keteguhannya mengantar mereka pada sikap loyal kepada prinsip pelayanan publik serta birokrasi kepada masyarakat. Kondisi itu menunjukkan masih dimilikinya nilai keteguhan tersebut dalam budaya organisasi di kantor DPMPTSP Kabupaten Sinjai.

Nilai-nilai ini sudah lama dikenal sebelum datangnya Islam, dan telah diaplikasikan oleh orang Bugis dalam budaya mereka. Keteguhan adalah sebuah prinsip keberanian menanggung resiko atas kejujuran, kebenaran, kepantasan, sehingga ia tidak akan mungkin goyah oleh godaan dan praktek pungutan liar dalam melakukan birokrasi dan pelayanan publik. Keberanian (awaraning) kadang harus menanggung resiko berpisahnya ruh dan jasad (kematian), tetapi itulah harga diri (siri'). "lebih baik mati berkalang tanah daripada hidup bercermin bangkai" adalah sebuah pribahasa yang sesuai dengan prinsip siri' dan agettengeng. Lebih baik kehilangan jabatan daripada menduduki jabatan yang tidak membawa manfaat bagi masyarakat dan bangsa. Sekali ia menduduki jabatan dan kewenangan, ia harus memberikan nilai dan manfaat bagi masyarakat secara adil (temmappasilaingeng). Jadi, jabatan tidak menjadi tujuan, melainkan sebagai kesempatan dan amanah berbuat sesuatu yang mendatangkan manfaat bagi negara dan rakyat.

\section{Nilai Budaya Sipakatau (saling menghormati) dan Sipakainge (saling mengingatkan)}

Nilai sipakatau, dan sipakainge tidak hanya sebagai nilai budaya yang sekedar diakui dalam masyarakat akan tetapi juga teraplikasi dalam tindakan. Artinya dalam hidup dan kehidupan termasuk dalam interaksi para aparatur di kantor DPMPTSP Kabupaten Sinjai, ketiga nilai tersebut bahkan menjadi pemersatu, sehingga mereka akan merasa saling melengkapi.

Bentuknya teraplikasi dalam tindakan perhatian atasan terhadap pegawai sangatlah dibutuhkan dalam menciptakan suasana kondisi organisasi yang nyaman dan kondusif. Dalam penyelenggaraan pelayanan perizinan, perhatian Kepala Bidang Penyelenggaraan Pelayanan Perizinan terhadap staff perizinan yang dimana mampu memberikan pengarahan dan saling mengingatkan agar dapat membuat semua anggota kelompok bekerja sama dan bekerja secara ikhlas sesuai tupoksi masing-masing, untuk membantu dalam pencapaian tujuan organisasi dan juga dalam pemberian motivasinya, harus dapat mendorong para staff perizinan untuk bekerja giat dan membina bawahan dengan baik, sehingga terciptanya suasana kerja yang baik dan harmonis.

Konsep nilai sipakatau dalam artian memosisikan manusia sebagai mahluk ciptaan Tuhan yang mulia oleh karenanya harus dihargai dan diperlakukan secara baik yang diimplementasikan dalam hubungan sosial yang harmonis yang ditandai oleh adanya hubungan intersubyektifitas dan saling menghargai sebagai sesama 
aparatur dengan atasan dalam proses penyelenggaran perizinan di Kantor DPMPTSP Kabupaten Sinjai.

“...Berpacu untuk selalu menjadi yang terbaik dan memberikan arahan dan petunjuk (saling mengingatkan) "sipakainge" sesuai dengan Standar Operasional Prosedur yang lebih baik kedepannya agar dapat saling berkompetensi secara positif tanpa harus ada yang merasa dirugikan, dukungan utama yang terjalin yakni saling memotivasi, mengingatkan antara satu dan lainnya dengan menjalin komunikasi yang lebih baik lagi, dalam pemberian motivasi, saya selalu mengingatkan bahwa segala sesuatu yang dikerjakan ada dua yang senantiasa kita tanamkan dalam hati yaitu yang pertama diniatkan dalam ibadah dan yang kedua adalah adanya perhargaan yang diberikan dari pimpinan maupun lembaga bagi pegawai yang memiliki prestasi dalam pekerjaanya..." (Kabid Pelayanan Perizinan DPMPTSP Kab. Sinjai, Wawancara Juli 2017)

Dari hasil studi berkenaan bentuk perhatian Kabid Penyelenggaraan Perizinan sudah dapat dikatakan baik, karena ketika ada salah satu staff perizinan memiliki masalah, Kasie Perizinan melalukan pendekatan untuk mengetahui masalah tersebut dan cara penyelesainnya tanpa merugikan pihak manapun. Sikap yang ditunjukkan oleh Kabid Penyelenggaraan Perizinan mencerminkan sikap sipakatau kepada seluruh staffnya, dengan memberikan solusi yang terbaik serta tidak mau merugikan siapapun karena dalam pandangan nya semua staffnya adalah manusia yang harus diperlakukan sama sesuai dengan segala hak-hak dalam kondisi apapun. Berdasarkan hasil analisis menggambarkan bahwa perhatian atasan terhadap pegawai di Kantor Dinas Penanaman Modal dan Pelayanan Satu Pintu (DPMPTSP) Kabupaten Sinjai sudah dapat dikatakan baik dan juga dukungan yang diberikan oleh atasan kepada pegawai nampak baik. Saling mengingatkan diantara aparatur yang berada di Kantor DPMPTSP menunjukkan tindakan dari nilai sipakainge tersebut. Kondisi itu membuat sistem pelayanan yang terdapat di kantor dapat berjalan secara efektif.

\section{Nilai budaya Ajjoareng-Joa (Patron-Klien)}

Konsep patron-klien telah terjadi sejak zaman Romawi kuno. Setiap bangsawan (patronus) mempunyai sejumlah orang dari tingkat strata yang lebih rendah (clientes) yang berharap perlindungan darinya. Para clientes sebenarnya adalah orang bebas namun realitasnya mereka tidak sepenuhnya merdeka. Hubungan mereka sangat dekat, hal ini terlihat pada nama keluarga pelindungnya mereka gunakan dan mereka ikut dalam upacara pemujaan keluarga bangsawan yang mereka anggap sebagai pelindung. Hubungan patron dan klien di Romawi dibangun berdasarkan hak dan kewajiban timbal-balik dan bersifat turun temurun. Patron berkewajiban untuk menjaga kliennya dari musuh-musuh dan melindunginya dari tuntutan hukum. Disamping itu patron juga membantu keluarga kliennya dalam hal ekonomi, dengan memberikan lahan kepada pengikutnya agar dapat menghidupi seluruh anggota keluarganya. Di sisi lain, klien juga berkewajiban untuk membantu patronnya dalam kondisi tertentu, seperti menebus sang patron jika ditangkap sebagai tawanan perang, atau membayar biaya perkara yang harus dibayar patron. 
Model patron-klien ini juga diterapkan pada berbagai masyarakat dalam berbagai periode sejarah. Hubungan patron-klein menjadi bagian dalam sistem social politik masyarakat di beberapa belahan bumi seperti di Eropa, misalnya di Italia dan juga di Amerika Latin, misalnya di Meksiko. Sedang patron-klien di Asia juga terjadi di Filipina, Burma, Thailand, dan Malaysia. Dan di Timur Tengah, seperti di Irak dan Iran.(Pelras, 1981)

Putra (1988) mengutip pendapat J.C. Scott yang menyatakan bahwa gejala patronklien tetap berlaku di masyarakat pada masa lalu hingga sekarang khususnya di masyarakat Asia Tenggara, disebabkan oleh tiga kondisi pendukung. Kondisi pertama adalah terdapatnya perbedaan (inequality) yang terjadi di masyarakat dalam hal kekayaan dan kekuasaan. Patron mendasarkan dirinya pada pengaturan kekuatan serta jalur mendapatkan jabatan. Bukan pada pewarisan kedudukan atau kepemilikan tanah. Kondisi ini berubah pada masa pemerintahan kolonial yang menerapkan komersialisasi ekonomi. Sehingga kepemilikan tanah kemudian menjadi pemicu munculnya gejala patron-klien.

Kondisi kedua ditandai dengan perbedaan penguasaan sumber daya yang kemudian tidak diikuti dengan adanya institusi yang dapat menjamin keamanan individu baik menyangkut status maupun kekayaan. Kondisi ini kemudian diperparah dengan kelangkaan sumber daya. Berimplikasi pada semakin besarnya resiko ketidakamanan fisik karena perbenturan kepentingan penguasaan sumber daya yang tidak dapat dihindari. Hubungan patronase sebagai salah satu cara untuk mendapatkan keamanan menjadi pilihan jika keamanan sudah semakin terancam dan kontrol social tidak bisa dijadikan tempat perlindungan. Memilih untuk "dekat" pada orang yang lebih kuat dengan harapan dapat melindunginya dari ancaman merupakan solusi terbaik masa itu. Sehingga secara realitas ikatanikatan pribadi telah menggantikan peranan hukum, nilai-nilai bersama dan institusi-institusi yang kuat.

Kondisi yang ketiga, jika ikatan-ikatan kekerabatan ternyata tidak dapat diandalkan sebagai satu-satunya cara untuk mencari perlindungan serta meningkatkan penguasaan sumberdaya. Efektifitas hubungan dalam kelompok kekerabatan menjadi semakin berkurang sejak diberlakukannya sistem ekonomi baru oleh pemerintahan kolonial. Untuk itu membina hubungan dengan orangorang di luar kerabat merupakan tindakan yang jauh lebih efektif untuk memperoleh kekayaan, status dan kekuasaan.

Ketiga kondisi pendukung tersebut mendeskripsikan kepada kita situasi yang melatarbelakangi hubungan patron-klien yang dianut oleh masyarakat Bugis biasa disebut Ajjoareng-Joa'. Dalam masyarakat Bugis, patron biasanya diduduki oleh kalangan bangsawan yang disebut Ajjoareng atau Pappuangeng. Sedang klien berasal dari kalangan masyarakat biasa yang disebut joa' atau ana' guru (pengikut). Hubungan patron dan klien merupakan hubungan kewajiban timbal-balik. Seorang patron berkewajiban untuk melindungi joa'nya dari kesewenang-wenangan dari bangsawan lain, pencurian, atau berbagai ancaman lain, serta memperhatikan 
kesejahteraan dan melindungi mereka dari kemiskinan. Sebaliknya, klien berkewajiban untuk memberikan pelayanan kepada patronnya, misalnya, dengan bekerja di lahan atau rumah tuannya, atau menjadi prajurit, dan mengerjakan berbagai kegiatan-kegiatan lainnya.

Dalam sistem politik orang Bugis tradisional, garis keturunan bukanlah jaminan untuk mendapatkan posisi jabatan politik. Tidak ada aturan mutlak/yang dapat dijadikan pedoman dalam proses suksesi suatu kerajaan. Namun terdapat sebuah petunjuk yang menggariskan bahwa untuk jabatan tertentu, calon yang akan dipilih biasanya mesti salah seseorang dari sekian banyak keturunan pemegang jabatan sebelumnya, dan dia sendiri berasal dari status tertentu saja. Jadi akan terdapat beberapa kandidat yang memiliki hak yang kurang lebih sama untuk berkompetisi dalam suksesi tersebut. Faktor utama yang dapat memenangkan adalah kandidat yang memiliki pengikut paling banyak serta didukung oleh pengikut yang paling berpengaruh. Jadi secara mendasar pengikut (joa') dapat dibedakan dua jenis. Pertama, pengikut dari kalangan orang biasa, yang mengabdi langsung kepadanya dengan, misalnya, menjadi prajurit dalam pasukannya. Kedua, adalah pengikut dari kalangan bangsawan yang menjadi pendukung, yang juga memiliki pengikut dan pendukung sendiri.

Berangkat dari fenomena tersebut di atas, maka seorang patron harus berupaya untuk memperluas jaringan kliennya. Terdapat beberapa cara untuk membangun dukungan jaringan klien. Pertama adalah dengan menunjukkan kedemawanan dan membangkitkan rasa hormat dari kalangan pengikut dengan melindungi dan menjaga kesejahteraan mereka lebih baik dibanding yang lain. Kedua adalah dengan membangkitkan kebanggaan pengikut dan harapan akan masa depan yang lebih baik dengan menduduki jabatan tinggi atau tampak sebagai orang yang paling berpeluang untuk menduduki jabatan tersebut. Pengikut pada gilirannya akan merasa ikut terhormat, dan berharap memperoleh keuntungan dari jabatan pemimpinnya, karena dengan memegang jabatan tersebut meningkatkan peluang patron mereka untuk mendistribusikan kembali kekayaan yang diperolehnya. Ketiga adalah melalui "perkawinan politik" yaitu dengan menikahi keturunan atau keluarga bangsawan yang memiliki joa' yang banyak serta pendukung yang berpengaruh atau kharismatik. (Pelras, 1981)

\section{- Implikasi nilai lokal dalam budaya organisasi}

Bagaimana pun juga, pengaruh budaya lokal dalam birokrasi dan pelayanan publik adalah hal yang wajar dalam tinjauan sosial-budaya, terlebih birokrasi dan pelayanan publik tersebut berada pada suatu wilayah tertentu dimana terdapat budaya yang khas. Implikasi tersebut dapat bernuansa atau bernilai positif maupun negatif, namun, kedua nilai dari implikasi yang dimaksud tidak dapat dipisahkan sebab terjadi secara kasuistik. Dalam kasus kinerja dalam DPMPTSP, budaya lokal dapat mempengaruhi alur kerja yang sebelumnya telah teratur berubah menjadi tidak teratur. Dalam arti, karena suatu kebutuhan, yang meski tidak mendesak, tetapi karena adanya ketiga wujud budaya lokal yang dimaksud sebelumnya maka alur kerja berubah. Kasus ini 
dapat berimplikasi positif yang mana membentuk pemahaman baru yang tidak disadari sebelumnya, bahwa alur kerja yang telah terstruktur mungkin saja salah, atau terlalu berbelit-belit, terlalu lama, dan/atau terlalu mahal. Kesadaran yang tidak disadari kemudian menjadi acuan dasar yang hanya muncul dari kasus-kasus dimana budaya lokal berinteraksi dengan birokrasi dan pelayan publik, sebab budaya lokal yang bersifat dinamik sementara birokrasi dan pelayanan publik bersifat terstruktur atau statis. Namun demikian, kasus semacam ini tentunya memiliki muatan negatif, yang mana karena itu alur kerja terlihat kacau. Dalam arti, bisa saja terjadi ketidakhirauan terhadap status, peran, aturan, atau yang dimaksud sebagai struktur, yang dapat berupa pelampauan wewenang atau pelampauan komando dan koordinasi.

Budaya lokal masyarakat bugis merupakan landasan perilaku ideal masyarakat bugis semenjak masa lampau. Berfungsi dalam berbagai hal seperti pengambilan keputusan, pemecahaan masalah, rasa persatuan dan kebersamaan pada tatanan masyarakat dan pemerintahan, walaupun tidak terlalu ditunjang oleh pengetahuan yang tinggi. Hal ini membawa kehidupan yang damai dan kondusif yang pada akhirnya akan membawa kesejahteraan masyarakat.

Model kehidupan dengan penuh nilai dalam menata kehidupan masyarakat dan pemerintahan terdapat dalam berbagai macam lontara orang terdahulu yang memuat nilai dalam berbagai aspek kehidupan yang tentunya sangat relevan dalam mewarnai era reformasi dengan konsep good governance yang nampaknya sudah dipraktekkan orang bugis masa lampau.

Budaya lokal orang bugis yang terangkai dalam nilai-nilai kebudayaan orang bugis masa lampau pada hakekatnya adalah penjelmaan dari tata pemerintahan yang baik seperti tuntutan era reformasi. Begitu banyak nilai-nilai yang dimiliki oleh orang bugis yang kemudian perlu diadopsi, namun dibatasi dengan pada hal yang relevan dalam upaya pengengolaan pemerintahan yang baik dengan berdasarkan pada geopolitik dimana nilai itu berlaku.

Secara garis besarnya yang sangat relevan diterapkan dalam pengengolaan pemerintahan yang baik berdasarkan geopolitik keberlakukan nilai-nilai tersebut. Dari beberapa nilai-nilai budaya yang dimiliki oleh orang bugis, yang nampaknya sejalan dan serasi dengan prinsip-prinsip good governance yang di rekonsepsi menjadi konsep kewajaran dengan nilai lempu (kejujuran), amaccang (kecendikiawan), astinajang (kepatutan), aggettengeng (keteguhan), sipakatau - sipakainge (saling menghargai), dan prinsip ajjoareng-joa.

“...Budaya amat dipengaruhi oleh mindset para elit dan aparat birokrasi pemerintah, namun budaya juga dapat mempengaruhi elit dan aparat birokrasi pemerintah dalam melakukan aktivitasnya sebagai pelayan masyarakat. Budaya birokrasi yang baik akan menciptakan pelayanan yang berkualitas, begitupun sebaliknya, budaya birokrasi yang buruk akan menciptakan pelayanan yang buruk pula. Sejalan dengan penciptaan budaya birokrasi yang lebih adaptif dan komunikatif sangat berkenaan dengan nasehat, prinsip, aturan dan norma, pedoman hidup dan nilai kepribadian yang sangat religius dalam masyarakat Sinjai yang senantiasa berpegang teguh pada prinsip "perjanjian tupekkong " artinya wasiat orang dahulu yang dapat dijadikan sarana untuk 
membentuk perilaku dan budaya birokrasi dalam penyelenggaraan pelayanan publik..." (Kepala Dinas Penanaman Modal Kab. Sinjai, Wawancara Januari 2018)

Dari konsep kewajaran yang mengadopsi nilai-nilai budaya lokal tersebut sejalan dengan prinsip pemerintahan yang baik yaitu transparansi, akuntabilitas dan kepastian hukum. Selain itu, indikator administrasi publik yang berorientasi pada manfaat dan efektifitas dalam pencapaian tujuan dan sebagai ilmu yang mengkaji tentang tatanan pemerintahan dan kemasyarakatan. Nilai budaya lokal masyarakat bugis sangat bersinergi dengan tata kelola pemerintahan yang baik, bahkan nilai-nilai pelayanan publik juga sejalan, sehingga penelitian mengacu pada nilai budaya dalam pelayanan publik.

Perilaku birokrasi ialah tingkah laku birokrasi dalam mensikapi tugas dan tanggung jawabnya yang dapat dilihat dari dua karakteristuj yaitu karakteristik individu meliputi kemampuan dan pengalaman, kebutuhan dan pengharapan, wewenang dan tanggungjawab, sistem pengawasan dan hirarki. (Rivai, 2003) Munculnya masalah yang mendasar pada implementasi pelayanan publik sangat bergantung pada perilaku birokrasi dalam melaksanakan tugas sebagai pelayan publik, pembangunanm regulasi, dan pemberdayaan. Memang pada dekade ini perilaku birokrasi telah mengarah pada patologi birokrasi. Salah satu bentuk patologi birokrasi adalah korupsi yang banyak terjadi pada saat ini.

\section{Adanya transparansi dalam pelayanan}

Budaya lokal masyarakat bugis dalam good governance yang berkaitan dengan tranparansi yakni nilai lempu, amaccang, dan astinajang yang mana ketiga nilai ini memaksa para birokrat yang berada di kantor DPMPTSP harus memiliki sikap transparansi dalam memberikan pelayanan publik kepada masyarakat.

Transparansi merupakan hal yang paling mendasar dalam pelayanan publik, namun masih sulit dilakukan secara maksimal, utamanya menyangkut kemampuan dan pengalaman birokrasi dalam melakukan pelayanan publik yang sangat terkait yang diterapkan dalam standar operasional prosedur (SOP). Pemerintahan yang baik harus mutlak melakukan transparansi boleh melakukan melalui pendekatan budaya lokal, utamanya dalam pelayanan publik. Transparansi dalam implementasi pelayanan publik tidak terlepas dari perilaku birokrasi sehingga kebutuhan dan pengharapan sebagai kebutuhan esensial birokrasi dapat bersinergi dengan bingkai budaya lokal masyarakat bugis.

Korelasi antara transparansi dalam konteks budaya lokal dari hasil studi lapangan menunjukkan bahwa wewenang bagi birokrat merupakan hal yang sering kontradiksi, mengingat wewenang bisa dipolitisir untuk kepentingan politik, utamanya pada proses pelayanan publik. Mengakibatkan tanggungjawab yang diembang juga tidak maksimal. Hasil studi lapangan juga menunjukkan budaya lokal dan transparansi ini belum bersinergi secara maksimal, karena sistem hirarki dan sistem pengawasan belum berjalan maksimal, utamanya dalam kaitan nya transparansi sebagai pemerintahan yang baik. 
Sinergitas transparansi dalam konteks budaya lokal masyarakat bugis dengan perilaku birokrasi merupakan hal yang mutlak, mengingat birokrasi sebagai pengemban amanah yang sarat akan tugas baik dalam kemampuan dan pengalaman, kebutuhan dan pengaharapan, wewenang dan tanggungjawab. Hal inilah yang memengaruhi perilaku birokrasi sehingga dibutuhkan nilai budaya lokal dalam mewujudkan transparansi terutama dalam konteks pelayanan publik.

\section{Adanya Akuntabilitas dalam kegiatan kantor}

Budaya lokal masyarakat bugis dalam good governance yang berkaitan dengan akuntabilitas adalah agettengeng (keteguhan), astinajang (kepatutan) dan lempu (kejujuran). Akuntabilitas sebagai salah satu prinsip good governance memegang peran penting dalam menciptakan pemerintahan yang baik, sehingga dalam perspektif pemerintahan dan administrasi publik, penyebab korupsi adalah rendahnya akuntabilitas birokrasi publik.

Akuntabilitas adalah ukuran yang menunjukkan apakah aktivitas pelayanan publik yang dilakukan oleh pemerintah sudah sesuai dengan norma dan nilai-nilai yang dianut oleh masyarakat dan apakah pelayanan publik tersebut mampu mengakomodasi kebutuhan masyarakat. Akutabilitas terkait dengan falsafah bahwa lembaga eksekutif pemerintah yang tugas utamanya adalah melayani rakyat harus bertanggung jawab secara langsung maupun tidak langsung kepada rakyat. Secara ringkas boleh dikatakan bahwa akuntabilitas ialah kesediaan untuk menjawab pertanyaan publik.

Korelasi antara akuntabiltas dab pelayanan publik dari hasil studi lapangan menunjukkan bahwa dalam proses pemberian pelayanan publik yang dilakukan oleh aparatur di DPMPTSP Kabupaten Sinjai telah mengalami sinergi dengan nilai budaya bugis yang mereka praktekkan seperti nilai agettengeng dan astinajang yang mereka aplikasikan dalam melakukan pelayanan publik, sehingga menunjukkan sikap positif dari pada pengguna layanan tersebut yaitu masyarakat.

\section{Jaminan kepastian hukum sebagai bentuk tanggungjawab}

Budaya lokal masyarakat Bugis dalam good governance yang berkaitanan dengan kepastian hukum adalah amaccang (kecendikiawan), astinajang (kepatutan), aggettengeng (keteguhan). Sebagai negara hukum, Indonesia berupaya membangun hukum nasional yang dimaksudkan untuk memberikan rasa keadilan, kepastian hukum dalam kemanfaatan dalam masyarakat. Salah satu pembangunan sistem hukum adalah budaya hukum yang berkaitan dengan sikap budaya masyarakat pada umumnya karena menyentuh keyakinan (belief), nilai (value), cita (idea) dan harapan (expectation).

Kesadaran hukum masyarakat merupakan pencerminan budaya hukum yang meliputi persepsi, pemahaman, sikap penerinaan, praktek penerimaan, dan penafsiran terhadap isi dan tata laksana hukum dalam upaya penciptaan penerintahan yang baik (good governance) yang salah satu prinsipnya adalah penegakan hukum sehingga birokrat sebagai implementor dapat mengedepankan 
aspek supremasi hukum dalam implementasi kebijakan publik sebagai sektor yang paling rawan daiam pelaksanaan pemerintahan dan pembangunan.

Untuk itu, dalam mengambil kebjakan pubik para pejabat mempunyai kewajiban agar senantiasa merujuk kepada nilai-nilai judisial yang berlaku. Nilai judisial sangat berkaitan dengan good governance yang menekankan bahwa yang penting bukan sekedar formal atau sistem perundangan yang berlaku melainkan nilai - nila keadilan yang dianut dalam ketatanegaraan dan yang acuan hukum - hukum kemasyarakatan Menafsirkan dan merumuskan nilai judisial secara tepat merupakan tugas yang sulit karena orang dituntut memaham konteks budaya, dan kesadaran politis masyarakat mengikuti perkembangan aspirasi masyarakat.

Namun itulah yang sesungguhnya merupakan sumber legitimasi kebijakan publik yang utarma dalam arti etis maupun juridis. Birokrat dalam menjalankan tugasnya berada ditengah-tengah kontradiksi antara pertimbangan pragmatis dan pertimbangan legalitas mampu menyeimbangkan antara preferensi pribadi, kemauan pembuat undang undang serta peraturan-peraturan yang berlaku tempat ia mengabdi. Disinilah dibutuhkan nilai utamanya nilai budaya lokal masyarakat Bugis dalam mrembentuk perilaku birokrasi dalam penerapan kepastian hukum sebagai wujud dari pemerintahan yang baik. Kepastian hukum sebagai salah satu pnnsip good governance dalam konteks nilai budaya masyarakat Bugis dengan perilaku birokrasi terhadap implementasi kebijakan publik yang menunjukkan kurang hubungan, utamanya nampak pada realisasi perilaku birokrasi dalam mengembang tugas sebagai implementor dalam proses implementasi kebijakan publik.

Pada prinsipnya krakteristik yang melekat pada birokrasi sebagai implementor tidak terlepas akan adanya kepastian hukum, mengingat acuan birokrasi dalam implementasi adalah aturan yang sangat terkait dengan hukum sehingga hal ini menjadi penting utamanya dalam mewujudkan good governance. Kepastian hukum dalam membimbing birokrat sebagai implementor merupakan hal mutlak, utamanya dalam mewarnai perilaku birokrasi terhadap implementasi kebijakan publik. Perilaku birokrasi dalam hal kemampuan dan pengalaman birokrat dalam fase impementasi tetap mengacu pada ketentuan yang berlaku sehingga tercipta kepastian hukum sebagai prinsip pemerintahan yang baik.

\section{Kesimpulan}

Internalisasi nilai-nilai lokal budaya Bugis yang terkait dengan pelayanan publik dalam pemerintah yang sesuai dengan good governance dalam hal ini mencakup nilai-nilai yang telah ada sejak masa lampau dan dianggap dapat bersinergi dalam prinsip-prinsip pelayanan serta berlaku dalam budaya masyarakat yang mendukung terlaksananya pelayanan publik yang maksimal seperti nilai lempu (kejujuran), amaccang (kecendikiawan), astinajang (kepatutan), aggettengeng (keteguhan), sipakatau - sipakainge (saling menghargai), dan prinsip ajjoareng.

Nilai-nilai lokal masyarakat Bugis sejalan dan serasi dengan prinsip-prinsip good governance yang direkonsepsi menjadi konsep kewajaran dengan nilai lempu (kejujuran), 
amaccang (kecendikiawan), astinajang (kepatutan), aggettengeng (keteguhan), sipakatau sipakainge (saling menghargai), dan prinsip ajjoareng. Konsep kewajaran yang mengadopsi nilai-nilai budaya lokal tersebut sejalan dengan prinsip pemerintahan yang baik yaitu transparansi, akuntabilitas dan kepastian hukum. Selain itu, indikator administrasi publik yang berorientasi pada manfaat dan efektifitas dalam pencapaian tujuan dan sebagai ilmu yang mengkaji tentang tatanan pemerintahan dan kemasyarakatan.

\section{Referensi}

Putra, H.S.A. (1988). Minawang; Hubungan Patron-Klien di Sulawesi Selatan. Yogyakarta: Gadjah Mada University Press.

Kausar. (2006). Budaya Patron-Klien Dalam Perilaku Birokrasi di Daerah. Stusi di Kabupaten Tulang Bawang Propinsi Lampung. Universitas Padjajaran.

Bryant, C., White, L.G. (1987). Manajemen Pembangunan Untuk Negara-Negara Berkembang. Jakarta: LP3ES.

Edgar, H.S. (1992). Organizational Culture and Leadership. (2nd Edition). Jossey-Bass, San Fransisco

Gunawan. (2004). Pengaruh Reformasi Sistem Birokrasi Terhadap Pelaksanaan Otonomi Daerah di Kabupaten Kendari, Universitas Padjajaran.

Immanuel, Y. (2006). Pengaruh Pengembangan Organisasi dan Budaya Organisasi terhadap Efektivitas Keorganisasian Lembaga Perkreditan Desa di Bali, Studi di Kabupaten Badung. Universitas Padjajaran.

Mariana, D. (2007). Pengaruh Budaya Organisasi Terhadap Perilaku Pejabat Publik: Studi pada Pemerintah Provinsi Jawa Barat. Universitas Padjajaran.

Mustopadidjaja, AR., Bintoro T. (1999). Administrasi Negara, Demokratisasi dan Masyarakat Madani. Jakarta: Lembaga Administrasi Negara.

Munadah. (2006). Studi perilaku birokrasi orang Makassar di Kabupaten Gowa. Universitas Hasanuddin

Munsi, H., Ismail, A. (2018). Informalitas dalam Formalitas: Sebuah Kajian Budaya Organisasi Perusahaan Keluarga. Jurnal Etnosia: Jurnal Etnografi Indonesia Vol. 3 No.2.

Parhusip. (2006). Pengaruh desain pekerjaan dan kompetensi terhadap kepuasan kerja dan implikasinya kepada kinerja pegawai. Universitas Hasanuddin

Painter, M., Peters, B.G. (2010). Tradition and Public Administration, London: Palgrave Macmilan

Pelras, C. (1981). Hubungan Patron Klein pada Masyarakat Bugis dan Makassar di Sulawesi Selatan. Monash University.

Rahim, R. (2011). Nilai-Nilai Utama Kebudayaan Bugis. Yogyakarta: Ombak.

Rivai, V. (2003). Kepemimpinan dan Perilaku Organisasi. Jakarta: PT. Raja Grafindo Persada.

Thamrin, H. (2013). Hukum Pelayanan Publik di Indonesia. Yogyakarta: Aswaja Pressindo.

Yani, A.A. (2016) An Indonesian Administrative Tradition Before The Colonization Period, Advances in Social Science, Education and Humanities Research, 84: 454-457 